\title{
The impact of self-employment on the economic integration of immigrants: Evidence from Germany
}

\section{Jan Brzozowski ${ }^{1}$ iD, Anke Lasek ${ }^{2}$}

\begin{abstract}
Traditional approaches in migration studies suggest that self-employment and entrepreneurial activities enhance the perspectives of economic advancement of immigrants in host countries. Therefore, in many popular destinations in Western Europe and Northern America, policies encouraging the self-employment of immigrants have been proposed. But does the self-employment contribute to the economic integration of immigrants? Is it a universal, one-way avenue that guarantees the successful insertion of foreigners in a new socio-economic environment? Based on the German Socio-Economic Panel dataset, this study empirically investigates the effect of self-employment on the economic integration of immigrants in one of the most important host countries in Europe. Our results demonstrate that the current self-employment status in Germany is associated with higher income in absolute and relative (self-assessment) terms. The immigrants with previous self-employment experience in Germany are less integrated than the average. This result indirectly shows that the business economy of immigrants is associated with a high risk of failure and not all self-employed individuals succeed in advancing in economic terms in a host country. Consequently, we argue that host countries should be more cautious in promoting entrepreneurship as the "perfect" and "universal" strategy that improves economic integration.
\end{abstract}

Keywords: immigrant self-employment, economic integration, economic activity

\section{INTRODUCTION}

There is no doubt that human migration has become a highly sensitive topic in public debate in the Western world. As the discussion on migration

\footnotetext{
1 Jan Brzozowski, Ph.D. (corresponding author), Assistant Professor at the Department of European Studies, Cracow University of Economics, Rakowicka 27, 31-510 Kraków, Poland, e-mail: jan.brzozowski@uek.krakow.pl (ORCID ID: 00000001-8517-3485)

2 Anke Lasek, M.A., Ph.D. student, Cracow University of Economics, Rakowicka 27, 31-510 Kraków, Poland, e-mail: al.tomasu@gmx.de (ORCID ID: 0000-0003-2039-8610)
}

Received 24 February 2018; Revised 19 June 2018; Accepted 15 July 2018 
issues in Western Europe is currently dominated by the negative images of the immigrant and refugee crisis (Hatton, 2016), the proponents of more liberal migration policies tend to advertise the most positive outcomes of immigration processes. Among the benefits which immigration provides to the host country, immigrant entrepreneurship is the most popular example of how newcomers can become productive and contribute to the economic well-being of the entire national economy (Sinnya \& Parajuli, 2012).

The benefits associated with immigrant entrepreneurship, which are identified in the academic literature, are at least three-fold. Firstly, the newcomers contribute to the entrepreneurial ecosystem in a host country: with the higher number of foreigners the knowledge spillover between immigrant and native communities occur and, consequently, such process contributes to an increased internationalization of newly established firms (Li, Isidor, Dau, \& Kabst, 2017). Secondly, the foreign-born managers can have better managerial skills and access to valuable foreign and ethnic business networks which, in turn, can contribute to a better performance of the firms compared to those that are managed by native managers (Kulchina, 2017). Thirdly, the immigrants tend to exhibit higher entrepreneurial propensity than the natives: for instance, in the UK $17.2 \%$ of foreign-born individuals have chosen self-employment, while for the British citizens it was only 10.4\% (Centre for Entrepreneurs and DueDil, 2014). In consequence, the foreigners are responsible for a substantial part of the businesses created in host countries. Just in the US, the share of immigrant entrepreneurs doubled from 13.3 percent in 1997 to $28.5 \%$ of all businesses run in this country in 2014 (Bizri, 2017).

This latter manifestation of entrepreneurial activity of immigrants is of particular importance for the major destination countries, as in such cases foreigners do not only create jobs for themselves but also for their family members and members of the co-ethnic community. Therefore, both many scholars and also experts and policy-makers, perceive the self-employment of immigrants as a path to successful economic integration (Brzozowski, 2017b). As a result, many public bodies at a local, regional and national level have adopted policies that encourage immigrant entrepreneurship (Rath \& Swagerman, 2016). Unfortunately, by adopting such policies, the public authorities are under the influence of a "taking for granted effect," presuming that entrepreneurship always leads to betterment in the economic position of an immigrant. The recent literature review on the linkage between entrepreneurship and economic integration clearly shows, that there is very limited evidence to support such claims (Brzozowski, 2017a).

On the contrary, many studies demonstrate the opposite: self-employed migrants obtain lower incomes than their wage-employed counterparts (Hjerm, 2004). Consequently, there is still a need to get a better understanding 
of how entrepreneurial activities can influence the economic position of immigrants in a host country. As Borjas $(2017$, p. 2) rightly points out in his recent essay, this knowledge is also crucial within the frame of the current debate on costs and benefits of international migration as "immigration does not improve everyone's well-being (...) There are winners and losers, and we will need to choose among difficult options."

Therefore, the main aim of this paper is to analyze the outcomes of the economic integration of immigrants and the role of self-employment in this regard. Using the representative household survey (German Socio-Economic Panel, henceforth: GSOEP), we investigate whether the current and former entrepreneurial experience of immigrants pay off in terms of their current economic performance. Our findings are somehow mixed: while we find support for the positive linkage between the current self-employment status and economic integration, the immigrants who used to have entrepreneurial experience in the past in Germany obtain significantly lower integration scores. This result indirectly indicates a potential detrimental effect of the failed business project on economic integration and shows that promoting immigrant entrepreneurship may not always be a suitable policy.

The structure of our paper is as follows: in the second section, we review the theoretical and empirical literature on immigrant entrepreneurship and economic integration to describe the potential linkage between those variables. The third section presents the research hypotheses and research methods. The fourth section presents the results of the empirical analysis while the fifth one discusses those results and compares them with the previous studies. The last section concludes the paper, offering policy recommendations and giving directions for further research.

\section{LITERATURE REVIEW}

To date, there is no fixed definition of the term or concept of immigrant self-employment among researchers due to constant changes in the world of immigration around the globe (Nestorowicz, 2012). Self-employment is generally associated with the immigrant starting his/her own business in the host country and not being in labor employment (Chiang, 2004; Ambrosini, 2013; OECD, 2015). Mostly, these seem rather small or mediumsized businesses (Chiang, 2004), although usually it is not discussed what is meant by those terms (i.e., threshold values, etc.). To run the business, the immigrant owners may either do this personally (Lechmann \& Wunder, 2017), include family members and/or employees (Chiang, 2004), and/or hire a local manager (Kulchina, 2017). Nevertheless, there are cases in which self- 
employment might be a sideline to a primary labor engagement (Szarucki, Brzozowski, \& Stankevičienè, 2016). For delineation purposes, the term entrepreneurship might be reserved for discussions of the conceptional work in the scientific field (Parker, 2004) or attitude (Nestorowicz, 2012; Glinka \& Brzozowska, 2015); self-employment is suggested to be rather used when it comes to examining practical or quantitative empirical aspects in scientific work (Parker, 2004; Nestorowicz, 2012, p. 3). For the purpose of this paper, we focus on the term self-employment in the sense of an immigrant being the owner of his/her business at his/her own account and risk (Parker, 2004, p. 6), independently of with or without employees.

Self-employment seems to be the preferred choice of immigrants to OECD countries to earn their living in host destinations (Nestorowicz, 2012; but not so in Switzerland as Guerra, 2012, investigated). It may be chosen for many reasons, of which, it seems, finding a solution against unemployment (Cruickshank \& Dupuis, 2015) or for social promotion especially for the lower class (e.g., in Italy, Ambrosini, 2013), rank highly. Among these immigrant groups, for instance, significant economic achievements are the creation of worker demand for the domestic field industries or service lines that had not existed in the host country before immigration (Ambrosini, 2013). Or the establishment of either new supply chains in the host country (with respect to food, services and leisure activities, cf. Ambrosini, 2013; Brzozowski, 2017b) or new supply chains within an ethnic enclave (Brzozowski, 2017a). As such, we believe self-employment affects economic integration and vice versa. Running a business in low-productivity and less attractive sectors, and being new to the country, however, seem to result in being less integrated (Sinnya \& Parajuli, 2012).

Nevertheless, when unemployment rates are high among those immigrants, this is mostly due to language and cultural challenges (Kushnirovich, 2015), the ability to support oneself, the possibility and/or opportunity to apply skills and qualifications to the new market, and as such the actual obtainment of work (Chiang, 2004). Especially at the early stages of the settlement process at the destination, social and cultural host capital is needed most by the immigrant (Cruickshank \& Dupuis, 2015) but is difficult to obtain or learn (Chiang, 2004). On the other hand, there are sample immigrant groups that move intentionally abroad as they are already "adequately resourced" from the very beginning by either self-employment backgrounds and/or sufficient "economic and symbolic capital" (Cruickshank \& Dupuis, 2015). Moreover, there is some evidence that EU countries are applying selective migration policies, and the same happens on the supply side, as high skilled migrants prefer countries with a production structure to apply their home skillset right from the beginning (Frattini, Fenoll, \& Siragusa, 2017). Also, self-employment might sometimes be 
chosen for the immigrants, i.e., by governments and the ways their immigrant support and policies ensure immigrant competencies become useful in the economy (Neumann, 2016) or fill specific economic gaps (Hou \& Wang, 2011). Consequently, the degree of economic integration differs from immigrant to immigrant and country to country.

Besides the absence of clear definitions and term delineation, it becomes clear from our literature review that there is a common understanding of what is meant by integration. Defining a fixed term, however, again seems challenging as it is multidimensionally facetted, encompassing many fields of science such as economic or social science (Kuhlman, 1991). Economic integration, after that, might be interpreted as "the process of change" for the immigrant in order to settle in the host country, mostly influenced by "attaining material welfare" through an "optimal allocation of resources which are scarce and alternatively applicable" (Kuhlman, 1991). Leicht et al. (2012), for instance, state that the level of integration depends on a future perspective of employment (i.e., self-employment) as well as its welfare effects in the form of earned income. With respect to Germany, as a matter of fact, and its heavy influx of migrants over the past years, there are new research areas developing analyze integration through the measuring the effects of so-called integration courses offered by the German government to immigrants, which focus on education in the German language and life in Germany to help them integrate into society (Boockmann \& Scheu, 2018). Proof for the EU countries shows, moreover, that the longer an immigrant is present at the destination, the degree of integration may rise through time and acquisition of host country-specific capital (Frattini et al., 2017). As a result, earning and profit levels may rise, as evidence from Sweden shows for self-employed immigrant men (Neumann, 2016). Successful host self-employment is, moreover, majorly dependent on human capital factors such as age, education and experience (Neumann, 2016; for more general see Haberfeld, Birgier, Lundh and Ellder (2017). Those who are older, with longer previous work experience either in labor or self-employment, tend to be more successful in their new businesses over time, but immigrant men do not necessarily reach parity with self-employed natives (Neumann, 2016).

Problematic in this course of discussion is, in our view, a preferred focus on successful self-employment in the host country. This may be - among other reasons - due to the "survivors" being visible and present, and as such may act as a role model attracting attention for what they do (Guerra, 2012, p. 7; Leicht et al., 2012, p. 6). Neumann (2016) points out explicitly that there is a failure among immigrant firms (Neumann, 2016, p. 3). Sinnya and Parajuli (2012) point out that those self-employed immigrants with a lower education and experience level may face a higher failure. Banks, in this respect, not 
providing loans so easily to immigrants is because of a "higher failure rate of immigrant business compared with native business" (Wayland, 2011, p. 33).

On the other hand, self-employment may come to an end calculably when the economy is doing better with wage job opportunities arising, and immigrants switching back to the labor market by choice (Sinnya \& Parajuli, 2012). Self-employment is therein explored either through cross-sectional approaches in which only one period is considered or through the panel approaches in which potential former business ownership experience seems neglected. In our view, this results in business failures not being properly addressed but should, however, be included in the research to better understand the whole process of integration through adaption. As such, in our view, longitudinal studies considering more than just one year of data analytics should be taken up despite the fact of experimental challenges known and acknowledged.

Generally, it seems, migrants start their business activity but fail to develop properly and soon close (Chrysostome, 2010). The number of foundings and closings of migrant business, along with the number of such self-employment businesses, may indicate the strengths of migrant selfemployment (Leicht et al., 2012). Existing datasets capture, however, mainly the "successful survivors" but do not consider what happens to the formerly self-employed due to the lack of accessible information on their previous occupation in the home country (or even in another host country before the current one (Kerr/ Kerr, 2010). GSOEP data, in this respect, provides a special source of accessing such data, both in Germany (host country) and in the home country (Brücker et al., 2014).

\section{RESEARCH METHODS AND HYPOTHESES}

Based on the literature review presented in the former section, we now turn to the formulation of the hypotheses that will guide our empirical analysis. We consider three distinct economic effects of self-employment on the economic integration in the host country. At first, many countries encourage the immigration of persons with entrepreneurial experience as there is an expectation that such persons are more skilled and talented than the average, and additionally they can contribute to business creation in the host country. Therefore, we expect that the self-employment status in the home country before migration increases the perspectives for successful economic integration:

Hypothesis 1: The former self-employment experience from their home country affects positively the economic integration of an immigrant in Germany. 
Secondly, according to the surveyed literature, immigrants usually choose self-employment in the host country because they hope to get a higher reward by running a business activity. Therefore, we expect a direct influence of the entrepreneurial activities on the economic performance of the immigrant:

Hypothesis 2: Current self-employment status is associated positively with immigrant economic integration in Germany.

Finally, migrants can and usually do switch occupations, looking for better economic alternatives. In such a case, the migrant may have former business experience but might now have wage employment status. If entrepreneurship is the "right" strategy for economic integration, it might have an indirect positive effect on the current economic activity of an immigrant, thanks to gained skills, competences and working experience. Consequently, we hypothesize that:

Hypothesis 3: Former self-employment experience in Germany is associated positively with immigrant economic integration.

In order to verify these hypotheses, we researched the economic integration of immigrants in Germany using data from the representative household survey (German Socio-Economic Panel, GSOEP). Since 1984, GSOEP is a wide-ranging representative longitudinal survey of about 11,000 German private households and more than 20,000 persons (annual sample size for data collection) ${ }^{3}$ which contains rich bibliographical information on the socio-economic activity of immigrants in Germany (Krohn, Kühne, \& Siegers, 2017; Goebel, 2015). We use the 2013 round of the survey, as it contains a more comprehensive composition of immigrant communities in the country including the "new" foreigners from Central and Eastern Europe. Moreover, due to the enrichment of the data with biographical information on the former employment statuses from the public registers, this round of survey enables pseudo-panel analysis (Brücker et al., 2014). As we are particularly interested in the self-employment status, we can include dummies for the self-employment experience in the home country and former self-employment experience of immigrants in Germany.

In our empirical analysis, we turn to quantitative methods, namely econometric analysis. In order to account for heterogeneous measures of economic integration we use three dependent variables: a natural logarithm of obtained income per capita in the immigrant household (Ln (income), continuous), probability of being employed full-time (fulltime, binary) and probability of obtaining a fair income (fair income, binary). The first measure accounts for the most objective indicator of economic performance while the second one is important from the political perspective of the host country,

3 https://data.soep.de/soep-core; asamples of SOEP are multi-stage random samples which are regionally clustered. The respondents (households) are selected by random-walk. The interview methodology of the SOEP is based on a set of pre-tested questionnaires for households and individuals. 
as traditionally the receiving society wants migrants to be legally employed and to pay taxes. The third one - fair income - is a more subjective measure which includes the perspective of the immigrant and one's personal wellbeing and satisfaction. Taken altogether, we believe that these three dependent variables provide a more comprehensive picture of the process of economic integration in a host country.

\section{EMPIRICAL ANALYSIS}

For the sake of our analysis, we use the GSOEP data set by restricting a sample to individuals in the working age (18-65) and excluding individuals who have never worked and/or are currently (at the moment of survey) on maternity leave. In our sample, which consists of 3,851 individuals, there is a slight predominance of males (51.44\%), the mean age is 39.58 years, and the average level of education is relatively low (10.10 years of education which accounts for a secondary level being completed).

We estimate the first equation (Ln (income)) with the OLS model. In the case of the second equation, with full time being the dependent variable we turn to firthlogit regression4. In the case of the third equation, it is estimated with the traditional logit model. The results of our empirical exercise are provided in Table 1.

In the case of the first equation with the dependent variable Ln (income), we include two specifications of the model. The first specification includes the most important socio-economic and personal characteristics of an immigrant. The effect of gender is significant for the level of income, and works in a surprising direction, as males are found to get lower income than females, while all other factors held constant. Still, this effect is rather small. The effect of age on income is positive and significant. The number of children affects negatively the income per capita per household. The second generation of immigrants gets a slightly higher income than the foreign-born persons but also the magnitude of this effect is not impressive.

Interestingly, migrants who came to Germany due to political factors and who sought asylum in this country, obtain a significantly smaller income than the average. The same effect can be observed in the case of immigrants who are Muslim. The level of human capital matters for the level of obtained income: both in the cases of an MA diploma obtained in a home country, while a BA diploma has a positive effect both in the case of German and home country tertiary institution, but the effect of a German diploma is stronger.

4 The firthlogit model is chosen because of the estimation problems of the logit model which fails to include the interaction between a former self-employment status with a job change. 
Table 1. Estimation results

\begin{tabular}{|c|c|c|c|c|c|c|c|c|}
\hline & \multicolumn{2}{|c|}{ Income (I) OLS } & \multicolumn{2}{|c|}{ Income (II) OLS } & \multicolumn{2}{|c|}{ full time (firthlogit) } & \multicolumn{2}{|c|}{ fair income (log reg) } \\
\hline & coef & se & coef & se & coef & se & coef & se \\
\hline Gender (male $=1$ ) & $-0.0896 * * *$ & 0.0153 & -0.0155 & 0.0149 & $1.9302^{* * *}$ & 0.0887 & -0.0107 & 0.0463 \\
\hline Age & $0.0345^{* * *}$ & 0.0046 & $0.0389 * * *$ & 0.0049 & $0.1880^{* * *}$ & 0.0290 & 0.0231 & 0.0259 \\
\hline $\mathrm{Age}^{\wedge} 2$ & $-0.0004 * * *$ & 0.0001 & $-0.0005^{* * *}$ & 0.0001 & $-0.0023 * * *$ & 0.0003 & -0.0004 & 0.0003 \\
\hline Married (dummy) & 0.0004 & 0.0175 & 0.0217 & 0.0187 & 0.0346 & 0.1074 & 0.0851 & 0.0961 \\
\hline Number of children & $-0.1133^{* * *}$ & 0.0037 & $-0.1199 * * *$ & 0.0040 & $-0.1470 * * *$ & 0.0231 & $-0.0877 * * *$ & 0.0206 \\
\hline Born in Germany (dummy) & $0.0376^{*}$ & 0.0210 & 0.0177 & 0.0226 & -0.1178 & 0.1297 & -0.1476 & 0.1139 \\
\hline Health condition & $0.0336 * * *$ & 0.0070 & $0.0588 * * *$ & 0.0074 & $0.3753^{* * *}$ & 0.0438 & $0.3370^{* * *}$ & 0.0404 \\
\hline Arrived before 1995 (dummy) & 0.0032 & 0.0219 & 0.0171 & 0.0235 & 0.1697 & 0.1371 & $0.2285^{*}$ & 0.1228 \\
\hline Arrived as refugee (dummy) & $-0.1126 * * *$ & 0.0244 & $-0.1470 * * *$ & 0.0262 & $-0.4072 * *$ & 0.1576 & -0.2165 & 0.1453 \\
\hline Christian (dummy) & 0.0147 & 0.0158 & 0.0188 & 0.0169 & 0.0650 & 0.0970 & $0.2039 * *$ & 0.0866 \\
\hline Muslim (dummy) & $-0.0694 * * *$ & 0.0203 & $-0.0812 * * *$ & 0.0218 & $-0.2802 * *$ & 0.1282 & -0.1686 & 0.1152 \\
\hline MA diploma in Germany (dummy) & -0.0226 & 0.0565 & -0.0005 & 0.0607 & -0.0635 & 0.3720 & 0.3777 & 0.2986 \\
\hline MA diploma in home country (dummy) & $0.1219 * * *$ & 0.0341 & $0.1322 * * *$ & 0.0367 & 0.0564 & 0.2071 & -0.0156 & 0.1844 \\
\hline BA diploma in Germany (dummy) & $0.2480 * * *$ & 0.0491 & $0.2730^{* * *}$ & 0.0528 & $0.6694 * *$ & 0.3311 & 0.3215 & 0.2596 \\
\hline BA diploma in home country (dummy) & $0.0593^{* *}$ & 0.0285 & $0.0633 * *$ & 0.0308 & 0.2305 & 0.1755 & 0.2189 & 0.1552 \\
\hline Level of German proficiency & $0.0185^{* *}$ & 0.0075 & $0.0341^{* * *}$ & 0.008 & $0.2684^{* * *}$ & 0.0461 & $0.1176 * * *$ & 0.0416 \\
\hline Full-time employment (dummy) & $0.2401 * * *$ & 0.0177 & & & & & & \\
\hline Unemployed (dummy) & $-0.2512 * * *$ & 0.0219 & $0.050 * * *$ & 0.016 & & & & \\
\hline Currently self-employed (dummy) & & & $0.1205^{* * *}$ & 0.0324 & & & $0.8583^{* * *}$ & 0.1601 \\
\hline Has changed job(s) in Germany (dummy) & -0.0036 & 0.0152 & $0.0475 * * *$ & 0.0161 & $0.7338 * * *$ & 0.0870 & $0.5193^{* * *}$ & 0.0780 \\
\hline Former self-employed in Germany (dummy) & & & $-0.2124 * *$ & 0.1024 & $-2.2164 * *$ & 0.9277 & -0.8204 & 0.7796 \\
\hline Job change*former self-employed in GER & & & $0.3924 * * *$ & 0.1850 & $4.0494 * *$ & 1.7550 & -0.1423 & 1.0971 \\
\hline Self-employed before migration (dummy) & & & -0.0343 & 0.0362 & $0.4252 * *$ & 0.2063 & $-0.3488^{*}$ & 0.1966 \\
\hline$\%$ of foreign staff in workplace & -0.0042 & 0.0248 & $0.1309 * * *$ & 0.0261 & $1.833^{* * *}$ & 0.1420 & $1.1818^{* * *}$ & 0.1238 \\
\hline Intensity of social contacts with Germans & $0.1046^{* * *}$ & 0.0205 & $0.1282^{* * *}$ & 0.0220 & $0.3678^{* * *}$ & 0.1282 & 0.0930 & 0.1168 \\
\hline Speaks foreign language (dummy) & $0.0507^{* * *}$ & 0.0149 & $0.0508^{* * *}$ & 0.0160 & $-0.1542 *$ & 0.0925 & -0.0644 & 0.0830 \\
\hline $\begin{array}{l}\text { Does not intend to stay permanently in } \\
\text { Germany (dummy) }\end{array}$ & $0.0945^{* * *}$ & 0.0157 & $0.0924 * * *$ & 0.0169 & -0.1096 & 0.0965 & -0.0819 & 0.0863 \\
\hline $\begin{array}{l}\text { Does not have a permanent residence status } \\
\text { (dummy) }\end{array}$ & $-0.1190 * * *$ & 0.0214 & $-0.1453 * * *$ & 0.023 & $-0.4390 * * *$ & 0.1351 & -0.0752 & 0.1215 \\
\hline Hours worked overtime & $0.0026 * * *$ & 0.0006 & $0.0056 * * *$ & 0.0006 & & & & \\
\hline Unskilled job (dummy) & $-0.0704 * * *$ & 0.0161 & $-0.0470 * * *$ & 0.0172 & & & & \\
\hline _cons & $5.6256 * * *$ & 0.1049 & $5.3232 * * *$ & 0.1119 & $-7.9233 * * *$ & 0.6745 & -2.9824 & 0.1965 \\
\hline Number of observations & 3239 & & 3239 & & 3500 & & 3500 & \\
\hline R2 & 0.51 & & 0.4325 & & 0.058 & & 0.0970 & \\
\hline
\end{tabular}

Note: ${ }^{* * *} p<0.01,{ }^{* *} p<0.05, * p<0.1$ 
Not surprisingly, the level of proficiency in the German language is positively associated with income. Employment status is a very important predictor of income: full-time employed individuals get a much higher income than the partially-employed immigrants (reference category), while an unemployed status works in the opposite direction. This finding confirms our choice for using full-time employment as the measure of interaction (in the second equation).

Unskilled job status and working overtime dummies have a significant and expected effect on the level of income (negative on the former, and positive on the latter) but their magnitude is rather small. The intensity of social contacts with German citizens is positively linked to income, showing the importance of social interaction for economic integration. Lack of permanent status is associated negatively with income while the dummy for the intention to stay in Germany temporarily has a positive influence on the dependent variable. Finally, foreign language proficiency positively affects obtained income.

The second specification of the model, with income as the dependent variable, introduces new independent variables which are crucial for our hypotheses verification. Current self-employment status has a positive and significant influence on the level of income. The effect of the former self-employment status is not so evident. The parameter for the former self-employment dummy is negative and significant at 5 percent: for those immigrants who started their business activity in Germany and failed, i.e, unsuccessful entrepreneurial experiences, leaves a negative mark on currently obtained income. However, this effect works only in the case of persons who are currently unemployed or economically inactive. Those immigrants who used to be self-employed, but were able to successfully switch economic activity to waged employment (interaction effect of dummies: former selfemployment in Germany and a job change), exhibit higher income levels. Finally, the former self-employment status of an immigrant in a home country does not have any significant influence on current income.

In the case of the second equation with fulltime (employment status) as a dependent variable, the effect of gender is in line with our expectations, since males tend to exhibit a much higher probability of being employed full-time than females, while all other factors held constant. This effect, combined with the negative effect of the number of children on the full-time employment probability, shows that female immigrants in Germany pursue rather traditional roles in the families in which the professional career is less important than family obligations at home. The effect of health conditions is positively linked to full-employment status (i.e., healthier immigrants obtain higher income) while refugee status is linked in a negative way. Once again, religious affiliation seems to affect the integration perspectives, as Muslim 
immigrants show a smaller propensity to become full-time employed than Christian and immigrants of other religions and atheists (the reference group). In terms of educational measures, only the bachelor diploma obtained in Germany seems to have a positive impact on full-time employment probability, and this effect is quite strong. Also, the level of German language proficiency works in the same direction.

Turning to the most important independent variables from the perspective of hypotheses verification, once again the former self-employment status is associated with a substantially lower probability to be fully employed. Once again, the interaction of a job change with former self-employment is positive and significant at 5 percent, showing that immigrants who move from selfemployment to other activities become more integrated from an economic aspect. In this equation, current self-employment status is not used as an independent variable; as for the most self-employed, this is the main economic activity (carried out on a full-time basis). In this model, the entrepreneurial experience from the host country (dummy self-employed before migration) is positively linked to full-time employment probability in Germany.

Finally, the last equation deals with the most subjective measure of integration: whether the immigrant obtains a fair income or not (based on a self-assessment of the individual). Some of the controls such as health condition, number of children or German language proficiency show the same signs and similar magnitude as in the previous model (with dependent variable full-time employment). There are some important differences: the gender, refugee status and Muslim affiliation become insignificant; the same can be observed in terms of the educational attainment measures. In the case of our hypotheses, current self-employment status is associated with a substantially higher self-assessment of obtained income. As in other equations, economic mobility expressed as a job change in Germany has a positive effect on the dependent variable. The former self-employment status in Germany and the interaction of the former self-employment in Germany with a job change are insignificant. Then, the self-employment experience before migration (from a source country) has a negative effect but at 10 percent a significance level.

\section{DISCUSSION}

The main aim of our study was to verify the hypotheses on the effect of current and former self-employment status on the economic integration of immigrants in Germany. In the case of the first hypothesis which suggested a positive linkage between the self-employment experience from the home country and economic integration in Germany, we have found mixed results: in the case 
of the first equation, the parameter was not significant; in the case of the second one it was positive and significant at 5 percent, and in the third one it was negative and significant at 10percent. Thus, we have found only partial support for the positive impact of previous self-employment status in the home country on economic integration in the host country. This finding has important implications for policy-making in the area of migration: as in the case of Hiebert (2008) who found that immigrants with entrepreneurial experience in the source country were less integrated than the rest of immigrants in Canada, we can confirm that entrepreneurial skills may not be perfectly transferable across international borders. Therefore, countries which aim at adopting selective migration policies to attract skilled workers should be more careful in designing the entry preferences for immigrant entrepreneurs.

As for the second hypothesis, on the positive impact of the current self-employment status on economic integration in Germany, we have found supportive evidence both in equation 1 (dependent variable: Ln of current per capita income) and equation 3 (dependent variable: probability of obtaining fair income). Thus, we have confirmed the results of previous studies (Constant \& Shachmurove, 2006; Constant, 2009; Liebermann, Suter \& Rutishauser, 2014) which show that currently self-employed immigrants exhibit higher integration outcomes than immigrants who pursue other forms of economic activity.

In the case of the third hypothesis, which suggested a positive link between former self-employment experience in Germany and immigrant economic integration, our results are somehow surprising. In the case of equation 1 and 2, this parameter displayed a negative sign at a significance level of 5 percent, while in the third equation it was also negative but not significant. Moreover, the interaction of former self-employment in Germany and job change dummies was positively associated with economic integration, and the magnitude of this effect was much stronger than for the dummy job change. Thus, we interpret these results as an indication that those migrants who have moved from a former self-employment status into waged employment, have been able to get a higher income and have a higher probability of obtaining full-time occupation than the average. Consequently, we have not found any supporting evidence for our hypothesis 3. Quite the opposite: our results clearly show that in our sample we have two groups of self-employed individuals: "winners" and "losers." The "winners" are those immigrants who have started in self-employment and have continued this activity until now. In their case, such economic activity yields higher returns than in the case of other migrants and it improves their economic integration. There are also "losers" - the individuals that started being self-employed but had to abandon this activity due to lower profitability. In such a case, the former "losers" who 
were able to move into waged employment could also advance in economic integration: but for those individuals who stayed in part-time employment or with unemployment status, the former entrepreneurial experience constitutes an additional burden and obstacle in economic advancement in Germany. This finding draws, once again, attention to the failed entrepreneurial projects, the incidence of which is substantial in the case of immigrants, especially in the case of necessity-driven types of entrepreneurship (Chrysostome, 2010). We argue that future studies on immigrant entrepreneurship and economic integration should also take into consideration the dynamics of entrepreneurial process, including failed business projects and moves between entrepreneurial activities and waged employment.

Moreover, we argue that host countries should be more cautious in promoting entrepreneurship as the "perfect" and "universal" strategy that improves economic integration. The self-employment strategy and entrepreneurial projects are connected to higher risk than waged employment: consequently, there are "winners" and "losers" of this strategy. Consequently, focusing on "losers" (i.e., individuals whose business project has failed) is also important from an integration and social policy perspective.

Finally, our study also provides interesting results from a socio-economic policy perspective, and integration policy in particular. For instance, the two groups perceived as "problematic" in public discourse on immigration: refugees and Muslims (Adida, Laitin, \& Valfort, 2016; Cheung \& Phillimore, 2017) - exhibit different integration outcomes, depending on the measure of integration chosen. In the case of absolute income per capita and fulltime employment, those two groups attain significantly lower integration scores, but when we take into consideration the measure of fair income, all this negative effect disappears. In such a case, both refugees and immigrants with Muslim religious affiliation are not significantly different than the rest of the immigrant population in the sample. Therefore, our study clearly shows that care must be taken when choosing the measures of economic, but also socio-cultural, integration of immigrants, and the only sound approach is to apply a set of heterogeneous measures to get a full picture of the phenomena being investigated.

Ironically, our study also provides some evidence that immigrants who stay in the ethnic enclave economy are - paradoxically - better integrated from an economic aspect. This finding goes against the predictions of former theoretical literature on that topic which suggests that better perspectives exist for immigrant businesses, which go beyond the ethnic enclave (Eraydin, Tasan-Kok, \& Vranken, 2010; Curci \& Mackoy, 2010). The parameter of the variable "the percentage of foreign staff in the workplace" is positive and significant in all equations (with the exception of the first specification of the 
first equation). We acknowledge that this measure is not perfect and does not capture all the complexities of the effect of an ethnic enclave economy on the economic performance of immigrants in the host country. We found this result interesting and stimulating for future studies on this aspect.

\section{CONCLUSION}

In our study, we have investigated the effect of current and past selfemployment status on the economic integration of immigrants in Germany taking into consideration three measures of integration: absolute income, full-time employment and fair income. We have found evidence that confirms hypothesis 2 on the positive relationship between current self-employment and economic integration. We have limited results to backup hypothesis 1 on the positive impact of the self-employment experience in the home country on economic integration in the host country. Finally, we have to reject hypothesis 3 on the positive impact of former self-employment status in Germany on current integration outcomes: on the contrary, such effect in the light of our results seems to be negative.

Therefore, our study offers important policy implications: we demonstrate that entrepreneurial failure is an important factor which hinders economic advancement of an immigrant in Germany, and the public authorities should be more cautious in promoting migrant entrepreneurship as a "universal" strategy for improving the economic integration of foreigners in a host country.

Our study, although based on a large and representative GSOEP sample, has some limitations that need to be addressed in future studies. We have enriched the cross-sectional dimension of dataset with pseudo-panel information on past economic activity dummies, but such information still does not provide a full picture on the real dynamism of economic activity of immigrant in the host country. Consequently, future research on economic integration should take into account the full panel datasets, including the future waves of GSOEP dataset.

In spite of this limitation, we believe our study provides valuable results that could help in improving the knowledge on the relationship between entrepreneurship and the economic integration of immigrants. We would like to point out the most important issues that need to be considered in the future:

- First, the inclusion of both "winners" and "losers" of the entrepreneurial activity - the failure rates of immigrant business is substantial, therefore the empirical analyses should take into the account both current entrepreneurs, and former ones, including the whole variety of past entrepreneurial forms and ideas (also the 
business projects that failed to materialize due to a set of specific constraints);

- Second, the awareness of the complexity of the economic integration project. As there are no ideal and widely accepted definitions of integration, the measures of such process achievement should be as heterogeneous and inclusive as possible. Using only one measure of economic integration as a dependent variable produces highly biased results.

- Third, the role of the ethnic enclave economy in the economic integration of both immigrant entrepreneurs and immigrants employed in the ethnic businesses is not yet fully explained and needs a closer investigation: both from a qualitative studies perspective, and the quantitative approaches, that use longitudinal data.

\section{References}

Adida, C. L., Laitin, D. D., \& Valfort, M. A. (2016). Why Muslim Integration Fails in Christian-Heritage Societies. Cambridge, MA: Harvard University Press.

Ambrosini, M. (2013). Immigration in Italy: Between economic acceptance and political rejection. Journal of International Migration and Integration, 14(1), 175-194.

Bizri, R. M. (2017). Refugee-entrepreneurship: A social capital perspective. Entrepreneurship \& Regional Development, 29(9-10), 847-868.

Borjas, G. (2017). The immigration debate we need. The New York Times, Feb, 27. Boockmann, B., \& Scheu, T. (2018). Integration der Geflüchteten in den Arbeitsmarkt: Ziele, Strategien und Hemmnisse aus sicht der Jobcenter. IAW Discussion Papers, (130), 1-33.

Brücker, H., Kroh, M., Bartsch, S., Goebel, J., Kühne, S., Liebau, E., Trübswetter, P., Tucci, I., \& Schupp, J. (2014). The new IAB-SOEP migration sample: An introduction into the methodology and the contents. SOEP Survey Papers, (216). Retrieved from https://www.econstor.eu/handle/10419/103964

Brzozowski, J. (2017a). Entrepreneurship and economic integration of immigrants: A critical review of literature. International Journal of Entrepreneurship and Innovation Management, online first, 1-21. https://doi. org/10.1504/IJEIM.2017.10009134

Brzozowski, J. (2017b). Immigrant entrepreneurship and economic adaptation: A critical analysis. Entrepreneurial Business and Economics Review, 5(2), 159-176.

Centre for Entrepreneurs and DueDil (2014). Migrant Entrepreneurs: Building Our Businesses, Creating Our Jobs. London: Centre for Entrepreneurs and DueDil.

Cheung, S. Y., \& Phillimore, J. (2017). Gender and refugee integration: A quantitative analysis of integration and social policy outcomes. Journal of Social Policy, 46(2), 211-230. 
Chiang, L. (2004). The dynamics of self-employment and ethnic business ownership among Taiwanese in Australia. IOM International Migration, 42(2), 153-173.

Chrysostome, E. (2010). The success factors of necessity immigrant entrepreneurs: In search of a model. Thunderbird International Business Review, 52(2), 137-152.

Constant, A. F. (2009). Businesswomen in Germany and their performance by ethnicity: It pays to be self-employed. International Journal of Manpower, 30(1/2), 145-162.

Constant, A., \& Shachmurove, Y. (2006). Entrepreneurial ventures and wage differentials between Germans and immigrants. International Journal of Manpower, 27(3), 208-229.

Cruickshank, P., \& Dupuis, A. (2015). The adaptation of intentional immigrant entrepreneurs: A case study. Entrepreneurial Business and Economics Review, 3(3), 77-93.

Curci, R., \& Mackoy, R. (2010). Immigrant business enterprises: A classification framework conceptualization and test. Thunderbird International Business Review, 52(2), 107-121.

Eraydin, A., Tasan-Kok, T., \& Vranken, J. (2010). Diversity matters: Immigrant entrepreneurship and contribution of different forms of social integration in economic performance of cities. European Planning Studies, 18(4), 521-543.

Frattini, T., Fenoll, A., \& Siragusa, K. (2017). Migration Observatory Report: Immigrants' integration in Europe. Italy: Amici del Centro Studi Luca d'Agliano.

Glinka, B., \& Brzozowska, A. (2015). Immigrant entrepreneurs: In search of identity. Entrepreneurial Business and Economics Review, 3(3), 51-76.

Goebel, J. (Ed.). (2015). SOEP 2013 - Documentation on biography and life history data for SOEP v30, SPEO Survey Papers 266: Series D. Berlin: DIW/SOEP.

Guerra, G. (2012). Determinants of immigrant self-employment rates and self-employment transitions: Evidence from Switzerland. Doctoral thesis. Switzerland: University of Lugano.

Haberfeld, Y., Birgier, D. P., Lundh, C., \& Ellder, E. (2017). Economic assimilation of immigrants arriving from highly developed countries: The case of German immigrants in Sweden and the US (The Institute for Evaluation of Labour Market and Education Policy Working Paper No. 26),1-47.

Hatton, T. J. (2016). Immigration, public opinion and the recession in Europe. Economic Policy, 31(86), 205-246.

Hiebert, D. (2008). Big potential, small reward? Business Class immigration to Canada. In C.R. Oliveira \& J. Rath (Eds.), Migrações Journal - Special Issue on Immigrant Entrepreneurship (pp. 32-47). Lisbon: ACIDI.

Hjerm, M. (2004). Immigrant entrepreneurship in the Swedish welfare state. Sociology, 38(4), 739-756.

Hou, F., \& Wang, S. (2011). Immigrants in self-employment. Perspective on Labour and Income, 23, 3-14. 
Kerr, S. P., \& Kerr, W. R. (2016). Immigrant entrepreneurship (NBER Working Paper No. 22385). Retrieved from http://www.nber.org/papers/w22385

Kroh, M., Kühne, S., \& Siegers, R. (2017). Documentation of sample sizes and panel attrition in the German socio-economic panel (SOEP) (1984 until 2015). SOEP Survey Papers 408: Series C. Berlin: DIW/SOEP.

Kulchina, E. (2017). Do foreign entrepreneurs benefit their firms as managers? Strategic Management Journal, 38(8), 1588-1607.

Kuhlman, T. (1991). The economic integration of refugees in developing countries: A research model. Journal of Refugee Studies, 4(1), 1-20. https://doi.org/10.1093/jrs/4.1.1

Kushnirovich, N. (2015). Economic integration of immigrant entrepreneurs. Entrepreneurial Business and Economics Review, 3(3), 9-27.

Leicht, R., Di Bella, J., Langhauser, M., Leiß, M., Volkert, M., \& Werner, L. (2012). Schöpferische Vielfalt der Kraft: Zugewanderte und ihre Unternehmen - Bedeutung, Triebkräfte und Leistungen von Migrantenunternehmen in Baden-Württemberg und Deutschland. Germany: Institut für Wirtschaftsforschung Universität Mannheim.

Lechmann, D., \& Wunder, C. (2017). The dynamics of solo self-employment: Persistence and transition to employership. Labour Economics, 49, 95105. https://doi.org/10.1016/j.labeco.2017.09.002

Li, C., Isidor, R., Dau, L. A., \& Kabst, R. (2017). The More the Merrier? Immigrant Share and Entrepreneurial Activities. Entrepreneurship Theory and Practice, 42(5), 698-733. https://doi.org/10.1177/1042258718795344

Liebermann, A. J., Suter, C., \& Rutishauser, K. I. (2014). Segregation or integration? Immigrant self-employment in Switzerland. Journal of International Migration and Integration, 15(1), 93-115.

Nestorowicz, J. (2012). Immigrant self-employment: definitions, concepts and methods. Central and Eastern European Migration Review, 1(1), 37-55.

Neumann, E. (2016). Performance and job creation among self-employed immigrants and natives in Sweden (Working paper series No. 11: Linnaeus University Centre for Labour Market and Discrimination Studies. Retrieved from http://www.diva-portal.org/smash/record.jsf?pi $d=$ diva2\%3A1072660\&dswid $=1729$

OECD/European Union. (2015). Indicators of Immigrant Integration 2015: Settling In. Paris: OECD Publishing.

Parker, S. (2014). The Economics of Self-Employment and Entrepreneurship. Cambridge: Cambridge University Press.

Rath, J., \& Swagerman, A. (2016). Promoting ethnic entrepreneurship in European cities: Sometimes ambitious, mostly absent, rarely addressing structural features. International Migration, 54(1), 152-166.

Sinnya, U. \& Parajuli, N. (2012). Immigrant entrepreneurship: Why immigrants choose to become self-employed? A qualitative study of South and Southeast Asian Immigrant entrepreneur in Uema City. Master Thesis Umea School of Business and Economics. 
Szarucki, M., Brzozowski, J., \& Stankevičienè, J. (2016). Determinants of self-employment among Polish and Romanian immigrants in Germany. Journal of Business Economics and Management, 17(4), 598-612.

Wayland, S. V. (2011). Immigrant Self-Employment and Entrepreneurship in the GTA: Literature, Data, and Program Review. Toronto, Canada: Metcalf Foundation and Maytree Foundation.

\begin{abstract}
Abstrakt
Tradycyjne studia migracyjne sugerowały, że samozatrudnienie i przedsiębiorczość wpływajq pozytywnie na pozycję ekonomicznq imigrantów w krajach docelowych. Dlatego w najważniejszych krajach przyjmujqcych, w Europie Zachodniej i Ameryce Północnej, zaczęto wdrażać polityki wspierajqce przedsiębiorczość wśród imigrantów. Ale czy samozatrudnienie naprawdę wpływa pozytywnie na ekonomicznq integrację imigrantów? Czy jest to uniwersalna strategia, gwarantujqca ich skuteczne zagniezdżenie w społeczno-ekonomicznej strukturze w miejscu osiedlenia? W niniejszym artykule korzystamy z panelowej bazy danych (German Socio-Economic Panel w Niemczech) by zbadać wpływ samozatrudnienia na ekonomicznq integrację imigrantów w jednym z najważniejszych krajów docelowych w Europie. Wyniki naszych badań wskazuja że aktualny status samozatrudnionego powiqzany jest z wyższym dochodem jednostki, zarówno $w$ sensie absolutnym, jak i relatywnym. Jednakże imigranci majqcy wcześniejsze doświadczenie samozatrudnienia sq gorzej zintegrowani niż przeciętny imigrant. Wskazuje to pośrednio na wyższy współczynnik porażki w przypadku biznesów imigrantów, co oznacza że nie wszyscy samozatrudnieni awansuja ekonomicznie w miejscu docelowym. W oparciu wyniki naszej analizy wskazujemy, że kraje docelowe powinny być ostrożniejsze w zakresie promowania przedsiębiorczości jako jedynej skutecznej strategii wspierajqcej ekonomicznq integrację imigrantów.
\end{abstract}

Słowa kluczowe: somozatrudnienie imigrantów, ekonomiczna integracja, ekonomiczna aktywność

\title{
Biographical notes
}

Jan Brzozowski, Assistant Professor at the Department of European Studies, Cracow University of Economics (Poland). He is currently a member of the editorial board of the Entrepreneurial Business and Economics Review and a member of the Committee for Migration Research of the Polish Academy of Sciences.

Anke Lasek, $1^{\text {st }}$ year Ph.D. student at the Cracow University of Economics (Poland). She holds a Master of Arts in Humanities and a Master's degree in Taxation. 